\title{
International Lending of Dutch Insurers and Pension Funds: the Impact of ECB Monetary Policy and Prudential Policies in the Host Country
}

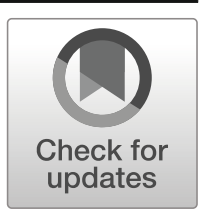

\author{
Jon Frost ${ }^{1,2,3} \cdot$ Patty Duijm $^{1} \cdot$ Clemens Bonner $^{1,2} \cdot$ Leo de Haan ${ }^{1}$. \\ Jakob de Haan ${ }^{1,4,5}$
}

Published online: 23 April 2019

(C) The Author(s) 2019

\begin{abstract}
We analyze the relationship between ECB monetary policy and prudential policies in the host country and international lending by Dutch insurers and pension funds, using confidential institution-specific data. Our results suggest that insurers and pension funds do not significantly change their foreign lending in response to ECB policy changes, proxied by a shadow rate capturing both conventional and unconventional monetary policies. However, our findings suggest that these financial institutions do increase foreign lending when banks in the host country are more constrained by prudential regulation, pointing to a substitution effect from banks to non-banks.
\end{abstract}

Keywords Monetary policy · Prudential policy · Pension funds · Insurance companies · Spillovers

JEL Classification F42 · F44 · G15 · G22 · G23

Jakob de Haan

jakob.de.haan@rug.nl

1 De Nederlandsche Bank, Amsterdam, The Netherlands

2 VU University, Amsterdam, The Netherlands

3 Financial Stability Board, Basel, Switzerland

4 University of Groningen, Groningen, The Netherlands

5 CESifo, Munich, Germany 


\section{Introduction}

Monetary policy is a powerful instrument. It can have far-reaching effects on asset prices, exchange rates, and other financial variables, and on financial institutions' risktaking behavior, and through these transmission channels on output and prices. The financial effects of monetary policy at the domestic level are the subject of substantial research (cf. Bernanke and Blinder 1992; Kashyap and Stein 2000; and van den Heuvel 2002), but also the international dimension is receiving increasing attention (see, for example, Bruno and Shin (2015); Cetorelli and Goldberg 2012; Avdjiev et al. 2016; Gagnon et al. 2017; and Nsafoah and Serletis 2019).

However, recent studies come to conflicting results regarding both the size and even the direction of the effects of monetary policy on foreign bank lending (see Argimón et al. 2019 for a discussion). This paper examines the effects of monetary policy changes on foreign lending by Dutch insurers and pension funds, based on confidential institution-specific data for the period 2006:Q1 to 2015:Q4. The effect of monetary policy on non-bank financial institutions has received hardly any attention in the literature, while insurers and pension funds play a very important role in the financial sector. In the Netherlands, the balance sheet of insurers and pension funds amounts to $80 \%$ and $120 \%$ of GDP, respectively. More generally, given the shift in credit provisioning in many economies from banks to non-banks, the response of non-bank financial institutions to monetary policy is highly relevant. ${ }^{1}$

In addition, we examine whether prudential policies in host countries affect foreign lending by Dutch insurers and pension funds. Our work thereby complements previous research by Frost et al. (2017) who analyze whether foreign bank lending by Dutch banks was affected by prudential policies in the host countries. Based on an analysis of the quarterly international claims of twenty-five Dutch banks in sixty-three countries over 2000-13, these authors report that Dutch banks increase lending in countries that tighten prudential regulation. ${ }^{2}$

Our research is part of the International Banking Research Network (IBRN) project on international spillovers of monetary policy. ${ }^{3}$ That is why our model specification is similar to that of Argimón et al. (2019) which focuses on the impact of central bank policies on international bank lending for the US, Spain and the Netherlands.

Monetary policy in the Netherlands has been set by the European Central Bank (ECB) during our sample period. Our time series also contains the period during which ECB policy rates have reached the effective lower bound (ELB). Since in this situation nominal interest rates only move marginally and the more general role of interest rates may change, it is commonly acknowledged that covariation between rates and other

\footnotetext{
${ }^{1}$ The IMF (2016) finds that both banks and non-banks contract their balance sheets when monetary policy tightens, but that non-bank financial intermediaries do so to a greater extent. Looking only at the insurance sector, Pelizzon and Sottocornola (2016) find that recent ECB monetary policy generally has a dampening impact on insurers' returns, although the effect of interventions changes over time. Neither of these studies focuses explicitly on the cross-border dimension.

${ }^{2}$ Ohls et al. (2017) and Damar and Mordel (2017) find similar results for German and Canadian banks, respectively.

${ }^{3}$ See Buch et al. (2019) for an overview of the project.
} 
variables, including lending, is almost entirely lost. To deal with this problem we use changes in the shadow bank rate, defined in Krippner (2015), as our proxy for monetary policy.

Our results suggest that insurers and pension funds do not respond to ECB monetary policy, but increase lending when banks in the host country are constrained by prudential regulation.

The paper is organized as follows. Section 2 discusses our data and describes some trends. Section 3 discusses our estimation method and presents the results. Section 4 concludes.

\section{Data and Trends}

\subsection{Data}

As prudential supervisor De Nederlandsche Bank (DNB) collects data from Dutch financial institutions for a variety of functions. Our data on foreign lending by insurance companies and pension funds is obtained from the balance of payment statistics, which contain detailed information on the holdings of assets, split by country of origin and sector, at an institutional level. An advantage of this granular dataset is that it contains information on transactions, i.e. the net purchases and sales of assets corrected for price and exchange rate effects. The data are available at quarterly frequency over the period 2006Q1-2015Q4. We zoom in on loans and bonds to the private sector. The private sector is defined as other insurance companies and pension funds, other financial institutions (excluding banks), households and non-financial institutions. For the analysis, data on the solvency position and total assets is also obtained, and stems from supervisory reporting. Our sample consists of 21 insurance companies and 28 pension funds. These institutions account (by assets) for over $70 \%$ of the Dutch insurance sector and nearly $80 \%$ of the Dutch pension fund sector, respectively.

\subsection{Trends in Foreign Lending}

Figure 1 shows the evolution of foreign claims of Dutch insurance companies and pension funds on the private sector. For insurance companies, there is a steady increase in foreign claims until 2010, when claims began to decline (panel A). In 2010, the share of foreign lending as a percentage of total lending equaled $36 \%$, while at the end of 2015 this was only $21 \%$. Dutch pension funds exhibit a large decrease in foreign holdings earlier, after 2009:Q1 (panel B). This decline is technical and is attributed to these institutions' shift towards investing in investment funds, which could be domiciled in the Netherlands but hold foreign securities. For the largest pension funds, we are able to "look through" the investments via investment funds and as such get insight in foreign securities invested in by pension funds but via investment funds. In our analysis, we have conducted a robustness check with this data including the investments via investment funds.

Table 1 presents some descriptive statistics for all insurance companies and pension funds in our sample. The foreign claims of both insurers and pension funds, 


\section{a Insurance companies}

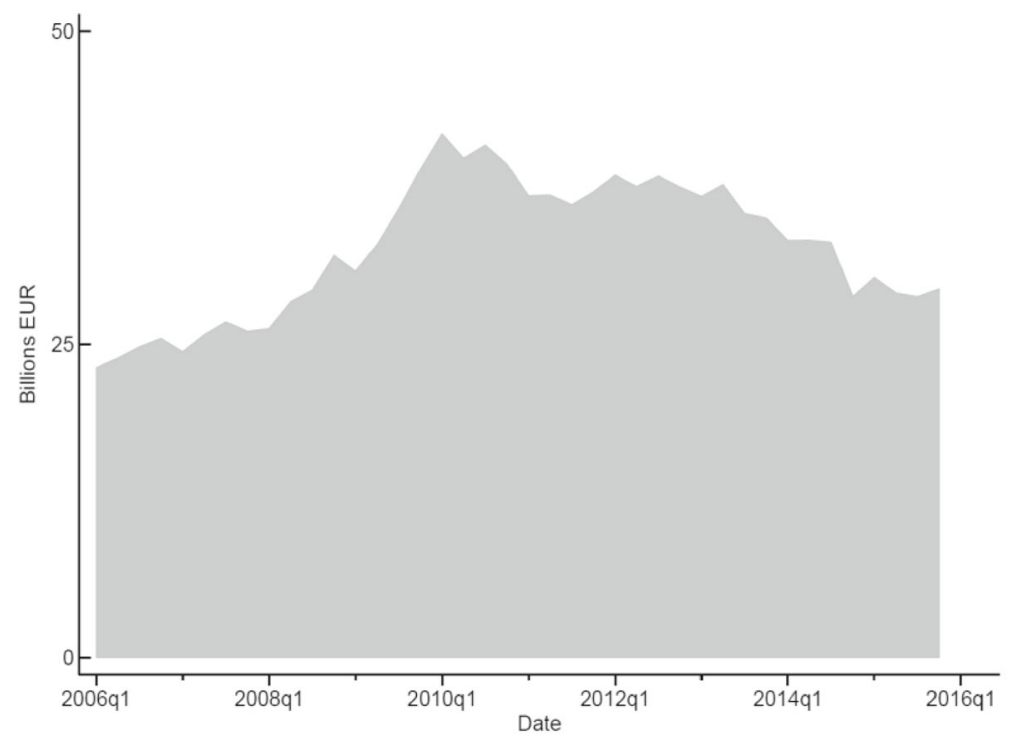

\section{b Pension funds}



Fig. 1 Foreign claims of Dutch insurance companies and pension funds (bln EUR)

representing $10 \%$ and $7 \%$ of total assets respectively, slightly decreased over the years 2006-2015. Table 1 also shows that, on average, pension funds are slightly larger than insurance companies. The relatively large standard deviation of the total assets confirm that the insurance and pension fund sectors are all quite concentrated with a handful of large institutions. 
Table 1 Summary statistics

\begin{tabular}{|c|c|c|c|c|}
\hline & $\begin{array}{l}\text { Total private foreign } \\
\text { claims/assets }\end{array}$ & $\begin{array}{l}\text { Log change total private } \\
\text { foreign claims }\end{array}$ & $\begin{array}{l}\text { Log total } \\
\text { assets }\end{array}$ & $\begin{array}{l}\text { Solvency } \\
\text { ratio }\end{array}$ \\
\hline & \multicolumn{4}{|l|}{ Insurance companies } \\
\hline Mean & 9.81 & -0.03 & 15.77 & 349.69 \\
\hline St. Dev. & 10.04 & 0.27 & 1.53 & 939.48 \\
\hline Min & 0.04 & -1.00 & 12.75 & 100.92 \\
\hline \multirow[t]{2}{*}{ Max } & 74.9 & 1.00 & 18.36 & 245.88 \\
\hline & \multicolumn{4}{|l|}{ Pension funds } \\
\hline Mean & 6.92 & -0.05 & 16.38 & 115.83 \\
\hline St. Dev. & 6.57 & 0.34 & 1.25 & 22.39 \\
\hline Min & 0.00 & -1.00 & 13.67 & 0.00 \\
\hline Max & 57.77 & 1.00 & 19.74 & 252.70 \\
\hline
\end{tabular}

\section{Empirical Method and Results}

\subsection{Model $^{4}$}

We use the following regression to explain how changes in ECB monetary policy affect changes in foreign lending by Dutch pension funds and insurance companies:

$$
\begin{aligned}
\Delta Y_{b, j, t}= & \alpha_{0}+\sum_{k=0}^{K}\left(\alpha_{1, k} \Delta M P_{t-k}^{\text {domestic }}+\alpha_{2, k} \Delta M P_{t-k}^{\text {domestic }} \text { Friction }_{b, t-K-1}\right)+\alpha_{3} \text { Friction }_{b, t-K-1} \\
& +\alpha_{4} X_{b, t-1}+\alpha_{5} Z_{t-1}^{\text {domestic }}+\alpha_{6} V I X_{t-1}+f_{j}+f_{b}+\varepsilon_{b, j, t}
\end{aligned}
$$

where $\Delta Y$ is the log change of foreign claims of institution $b$ on country $j$ at time $t$; we use total claims on foreign private borrowers. We include a vector of institution-specific controls $\left(X_{b, t-1}\right)$. More specifically, we control for an institution's size, solvency, liquid assets ratio and the international activities ratio. ${ }^{5}$ To control for conditions in the home country $\left(Z_{t-1}^{\text {domestic }}\right)$, we use proxies for the business cycle, i.e. the GDP gap (BIS 2014), and the financial cycle, captured by the credit-to-GDP gap (see Drehmann et al. 2011). We also control for host country characteristics $\left(Z_{j, t-1}\right)$. The business and the financial cycle proxies for the host country are used to control for host country demand conditions. As mentioned before, we also consider capital requirements on banks in destination countries, drawing on the IBRN prudential instrument database as described in Cerutti et al. (2017). This measure captures tightening or loosening of capital requirements in destination country $j$ at time $t$. It has a value of +1 when prudential measures are tightened, and -1 when measures are loosened. We use the VIX to

\footnotetext{
${ }^{4}$ This part of the paper heavily draws on the description of the IBRN approach provided in Argimón et al. (2019).

${ }^{5}$ Size is measured by total assets and solvency is measured by the total own funds over the solvency requirements. The liquid assets ratio represents the total cash over assets and the international activities ratio is measured by the total foreign claims over assets.
} 
control for international market conditions which may affect changes in the pace of growth of foreign claims $\left(V I X_{t-1}\right) . \Delta M P_{t-k}^{\text {domestic }}$ is the first difference of the ECB shadow rate (from Krippner 2015). ${ }^{6}$ We use $\mathrm{K}=3$, i.e. monetary policy over the current and last three quarters (one year in total). For insurers and pension funds the shadow rate seems to be the best way to capture monetary policy effects on their foreign lending behavior since these institutions are expected to mainly react to changes in the yield curve, and not to the short-term policy rate. Lastly, all regressions include host-country fixed effects and institution fixed effects. Standard errors are clustered at the institution level.

The coefficients $\alpha_{1, \mathrm{k}}$ and their annual cumulative effect captured by $\Sigma \alpha_{1, \mathrm{k}}$ allow us to test the overall relationship between ECB monetary policy and the change in foreign claims. However, this does not provide information on the specific frictions through which monetary policy affects the international activities of global financial institutions. This direct relation may also be weakly identified, as credit demand factors are difficult to control for. We expect that the direct effect of a monetary policy tighteningcaptured by $\Sigma \alpha_{1, \mathrm{k}}$-is negative. To better identify the channels of monetary policy transmission, we use the technique introduced by Kashyap and Stein (2000) and later applied by Cetorelli and Goldberg (2012) by introducing a set of regressors labeled Friction. These variables allow us to identify the effect of monetary policy in the crosssection of financial institutions, which mitigates some of the concerns related to the potentially endogenous determination of monetary policy. In the specification, the coefficients of interest are $\alpha_{2, \mathrm{k}}$, which capture the differential effect of monetary policy on foreign claims, conditional on these frictions. With $\alpha_{3}$ we control for the impact of the friction itself.

\subsection{Regressions for Lending by Insurers}

Table 2 shows the regression results for insurance companies. The baseline results in column (1) with the shadow rate as proxy for monetary policy, show that foreign lending by insurance companies does not respond to changes in monetary policy. Likewise, the coefficients on the interaction between monetary policy changes and the solvency rate (column (2)) and the size of insurers (column (3)) turn out to be insignificant. The overall impact, i.e. the cumulative effect of all coefficients, is similarly insignificant. However, as shown in column (4), insurers tend to increase their foreign lending to countries that increase their bank capital requirements. Hence, the increased activities of insurance companies in these countries can probably be seen as a substitution for bank lending that may be refrained by higher capital requirements (see Cizel et al. 2019 for a discussion). In economic terms, insurers lend about $3.8 \%$

\footnotetext{
${ }^{6}$ As pointed out by Claus et al. (2016), the shadow short rate is a synthetic summary measure that is derived from yield curve data and essentially reflects the degree to which intermediate and longer maturity interest rates are lower than would be expected if a zero policy rate prevailed in the absence of unconventional policy measures. This measure is better at capturing the effect of monetary policy on financial institutions' assets, especially in the effective lower bound (ELB) period. As policy rates reached the ELB, the value of longer dates assets may have changed, as several central banks started their quantitative easing programs. The shadow rate incorporates this information. Although during most of the period under consideration monetary policy was loosened, there were also periods when policy became more restrictive. For instance, there is a monetary tightening cycle just prior to the Global Financial Crisis (GFC), and again briefly in 2011.
} 
Table 2 Insurance companies

\begin{tabular}{|c|c|c|c|c|}
\hline & (1) & (2) & (3) & (4) \\
\hline & ECB policy rate & Solvency & Size & Capital requirements \\
\hline$\Sigma \Delta$ Domestic & 0.000 & -0.017 & 0.126 & 0.005 \\
\hline$M P_{t}$ to $t-3$ & $(0.969)$ & $(0.448)$ & $(0.391)$ & $(0.655)$ \\
\hline$\Sigma \Delta$ Domestic & & 0.006 & -0.008 & \\
\hline $\mathrm{MP}_{\mathrm{t} \text { to } \mathrm{t}-3} * \mathrm{Channel}_{\mathrm{t}-4}$ & & $(0.309)$ & $(0.361)$ & \\
\hline $\begin{array}{l}\text { Total effect of } \Sigma \Delta \text { MP terms } \\
\text { for the median institution }\end{array}$ & & $\begin{array}{l}-0.010 \\
(0.560)\end{array}$ & $\begin{array}{l}0.118 \\
(0.394)\end{array}$ & \\
\hline Log total assets $\mathrm{t}_{\mathrm{t}-1}$ & $\begin{array}{l}0.003 \\
(0.886)\end{array}$ & $\begin{array}{l}-0.020 \\
(0.445)\end{array}$ & & $\begin{array}{l}0.002 \\
(0.947)\end{array}$ \\
\hline Solvency ratio ${ }_{t-1}$ & $\begin{array}{l}0.000 \\
(0.815)\end{array}$ & & $\begin{array}{l}-0.003 \\
(0.314)\end{array}$ & $\begin{array}{l}0.001 \\
(0.565)\end{array}$ \\
\hline Liquid asset ratio $\mathrm{t}_{\mathrm{t}-1}$ & $\begin{array}{l}0.384 * \\
(0.093)\end{array}$ & $\begin{array}{l}0.214 \\
(0.272)\end{array}$ & $\begin{array}{l}0.250 \\
(0.257)\end{array}$ & $\begin{array}{l}0.208 \\
(0.410)\end{array}$ \\
\hline International activities ratio ${ }_{\mathrm{t}-1}$ & $\begin{array}{l}0.070 \\
(0.743)\end{array}$ & $\begin{array}{l}-0.073 \\
(0.714)\end{array}$ & $\begin{array}{l}-0.119 \\
(0.570)\end{array}$ & $\begin{array}{l}-0.908 \\
(0.179)\end{array}$ \\
\hline Channel $_{\mathrm{t}-4}$ & & $\begin{array}{l}-0.004 * * \\
(0.030)\end{array}$ & $\begin{array}{l}-0.030 \\
(0.168)\end{array}$ & \\
\hline Capital requirements $\mathrm{s}_{\mathrm{j}, \mathrm{t}-1}$ & & & & $\begin{array}{l}0.038 * * * \\
(0.005)\end{array}$ \\
\hline Business cycle domestic $_{\mathrm{t}-1}$ & $\begin{array}{l}0.003 \\
(0.493)\end{array}$ & $\begin{array}{l}0.002 \\
(0.541)\end{array}$ & $\begin{array}{l}0.002 \\
(0.611)\end{array}$ & $\begin{array}{l}0.010 * * \\
(0.015)\end{array}$ \\
\hline Business cycle $_{\mathrm{j}, \mathrm{t}-1}$ & $\begin{array}{l}0.531 \\
(0.111)\end{array}$ & $\begin{array}{l}0.669 * * \\
(0.044)\end{array}$ & $\begin{array}{l}0.648^{*} \\
(0.052)\end{array}$ & $\begin{array}{l}0.259 \\
(0.460)\end{array}$ \\
\hline Financial cycle domestic $\mathrm{t}_{\mathrm{t}-1}$ & $\begin{array}{l}-0.003 * * * \\
(0.001)\end{array}$ & $\begin{array}{l}-0.003 * * * \\
(0.003)\end{array}$ & $\begin{array}{l}-0.003 * * * \\
(0.005)\end{array}$ & $\begin{array}{l}-0.004 * * * \\
(0.000)\end{array}$ \\
\hline Financial cycle $_{\mathrm{j}, \mathrm{t}-1}$ & $\begin{array}{l}0.067 \\
(0.110)\end{array}$ & $\begin{array}{l}0.094 * * \\
(0.019)\end{array}$ & $\begin{array}{l}0.093 * * \\
(0.020)\end{array}$ & $\begin{array}{l}0.084 * \\
(0.067)\end{array}$ \\
\hline$\Delta \mathrm{MP}_{\mathrm{j}, \mathrm{t}-1}$ & $\begin{array}{l}-0.011 \\
(0.121)\end{array}$ & $\begin{array}{l}-0.007 \\
(0.229)\end{array}$ & $\begin{array}{l}-0.007 \\
(0.215)\end{array}$ & $\begin{array}{l}-0.012 * \\
(0.091)\end{array}$ \\
\hline $\mathrm{VIX}_{\mathrm{t}-1}$ & $\begin{array}{l}0.000 \\
(0.682)\end{array}$ & $\begin{array}{l}0.000 \\
(0.824)\end{array}$ & $\begin{array}{l}0.000 \\
(0.932)\end{array}$ & $\begin{array}{l}0.000 \\
(0.486)\end{array}$ \\
\hline Observations & 5200 & 5029 & 5029 & 4727 \\
\hline $\mathrm{R}^{2}$ & 0.084 & 0.084 & 0.082 & 0.093 \\
\hline $\mathrm{R}^{2}$ adj & 0.073 & 0.071 & 0.070 & 0.080 \\
\hline
\end{tabular}

This table shows the regression results for all insurance companies over the period 2006Q1-2015Q4. The dependent variable is the log change in total non-bank private claims to host country $\mathrm{j}$ over period $\mathrm{t}$ divided by total non-bank private claims in period t-1. Domestic exposures are excluded. All regressions are estimated by Ordinary Least Squares (OLS) accounting for insurer, quarter and host country fixed effects. Standard errors are clustered by institution, and ***,** and $*$ indicate significance at the $1 \%, 5 \%$ and $10 \%$ level, respectively

more a quarter after bank capital requirements were tightened, relative to quarters where no action was taken. Moreover, insurance companies lend more to countries with a higher credit-to-GDP gap, representing an upturn in the financial cycle and potentially more profitable (short-term) investment opportunities. Results (not reported for brevity) are similar when splitting the sample into the period before and after the ELB was reached. 


\subsection{Regressions for Lending by Pension Funds}

Table 3 shows the regression results for pension funds for the full period 2006Q12015Q4. The results in Table 3 show that, like insurers, pension funds do not increase their foreign lending in response to monetary policy changes. Likewise, we do not find evidence for a significant interaction between monetary policy and pension funds'

Table 3 Pension funds

\begin{tabular}{|c|c|c|c|c|}
\hline & (1) & (2) & (3) & (4) \\
\hline & ECB policy rate & Solvency & Size & Capital requirements \\
\hline $\begin{array}{l}\Sigma \Delta \text { Domestic } \\
\mathrm{MP}_{\mathrm{t} \text { to } \mathrm{t}-3}\end{array}$ & $\begin{array}{l}-0.011 \\
(0.531)\end{array}$ & $\begin{array}{l}0.040 \\
(0.618)\end{array}$ & $\begin{array}{l}-0.176 \\
(0.345)\end{array}$ & $\begin{array}{l}-0.013 \\
(0.481)\end{array}$ \\
\hline $\begin{array}{l}\Sigma \Delta \text { Domestic } \\
\mathrm{MP}_{\mathrm{t} \text { to } \mathrm{t}-3} * \text { Channel }_{\mathrm{t}-4}\end{array}$ & & $\begin{array}{l}-0.043 \\
(0.518)\end{array}$ & $\begin{array}{l}0.010 \\
(0.394)\end{array}$ & \\
\hline $\begin{array}{l}\text { Total effect of } \Sigma \Delta \text { MP terms } \\
\text { for the median institution }\end{array}$ & & $\begin{array}{l}-0.003 \\
(0.901)\end{array}$ & $\begin{array}{l}-0.167 \\
(0.342)\end{array}$ & \\
\hline Log total assets $_{\mathrm{t}-1}$ & $\begin{array}{l}0.142 * * * \\
(0.003)\end{array}$ & $\begin{array}{l}0.147 * * * \\
(0.004)\end{array}$ & & $\begin{array}{l}0.201 * * * \\
(0.000)\end{array}$ \\
\hline Solvency ratio t-1 $_{1}$ & $\begin{array}{l}0.050 \\
(0.123)\end{array}$ & & $\begin{array}{l}0.046 \\
(0.186)\end{array}$ & $\begin{array}{l}0.033 \\
(0.293)\end{array}$ \\
\hline Liquid asset ratio ${ }_{t-1}$ & $\begin{array}{l}1.441 * * * \\
(0.000)\end{array}$ & $\begin{array}{l}1.420 * * * \\
(0.001)\end{array}$ & $\begin{array}{l}1.370 * * * \\
(0.001)\end{array}$ & $\begin{array}{l}1.379 * * * \\
(0.001)\end{array}$ \\
\hline International activities ratio ${ }_{\mathrm{t}-1}$ & $\begin{array}{l}0.204 * * \\
(0.015)\end{array}$ & $\begin{array}{l}0.200 * * \\
(0.020)\end{array}$ & $\begin{array}{l}0.211 * * \\
(0.013)\end{array}$ & $\begin{array}{l}0.357 \\
(0.419)\end{array}$ \\
\hline Channel $_{\mathrm{t}-4}$ & & $\begin{array}{l}0.094 * * \\
(0.011)\end{array}$ & $\begin{array}{l}0.163 * * * \\
(0.001)\end{array}$ & \\
\hline Capital requirements ${ }_{\mathrm{j}, \mathrm{t}-1}$ & & & & $\begin{array}{l}0.016 \\
(0.184)\end{array}$ \\
\hline Business cycle domestic $\mathrm{c}_{\mathrm{t}-1}$ & $\begin{array}{l}-0.006 \\
(0.290)\end{array}$ & $\begin{array}{l}-0.011 \\
(0.036)\end{array}$ & $\begin{array}{l}-0.008 \\
(0.157)\end{array}$ & $\begin{array}{l}0.001 \\
(0.816)\end{array}$ \\
\hline Business cycle $_{\mathrm{j}, \mathrm{t}-1}$ & $\begin{array}{l}0.167 \\
(0.699)\end{array}$ & $\begin{array}{l}0.247 \\
(0.579)\end{array}$ & $\begin{array}{l}0.232 \\
(0.614)\end{array}$ & $\begin{array}{l}-0.010 \\
(0.983)\end{array}$ \\
\hline Financial cycle domestic $c_{t-1}$ & $\begin{array}{l}0.003 * * \\
(0.047)\end{array}$ & $\begin{array}{l}0.003 * * \\
(0.015)\end{array}$ & $\begin{array}{l}0.004 * * * \\
(0.008)\end{array}$ & $\begin{array}{l}0.003 * * \\
(0.012)\end{array}$ \\
\hline Financial cycle $_{\mathrm{j}, \mathrm{t}-1}$ & $\begin{array}{l}0.026 \\
(0.613)\end{array}$ & $\begin{array}{l}0.027 \\
(0.623)\end{array}$ & $\begin{array}{l}0.027 \\
(0.620)\end{array}$ & $\begin{array}{l}0.073 \\
(0.130)\end{array}$ \\
\hline$\Delta \mathrm{MP}_{\mathrm{j}, \mathrm{t}-1}$ & $\begin{array}{l}0.000 \\
(0.966)\end{array}$ & $\begin{array}{l}0.004 \\
(0.371)\end{array}$ & $\begin{array}{l}0.003 \\
(0.360)\end{array}$ & $\begin{array}{l}-0.001 \\
(0.867)\end{array}$ \\
\hline $\mathrm{VIX}_{\mathrm{t}-1}$ & $\begin{array}{l}-0.002^{* *} \\
(0.013)\end{array}$ & $\begin{array}{l}-0.002 * * * \\
(0.004)\end{array}$ & $\begin{array}{l}-0.002 * * * \\
(0.001)\end{array}$ & $\begin{array}{l}-0.002 * \\
(0.060)\end{array}$ \\
\hline Observations & 8828 & 8662 & 8662 & 7934 \\
\hline $\mathrm{R}^{2}$ & 0.100 & 0.102 & 0.100 & 0.103 \\
\hline $\mathrm{R}_{\text {adj }}^{2}$ & 0.092 & 0.094 & 0.092 & 0.095 \\
\hline
\end{tabular}

This table shows the regression results for all pension funds over the period 2006Q1-2015Q4. The dependent variable is the log change in total non-bank private claims to host country $\mathrm{j}$ over period $\mathrm{t}$ divided by total nonbank private claims in period t-1. Domestic exposures are excluded. All regressions are estimated by Ordinary Least Squares (OLS) accounting for pension fund, quarter and host country fixed effects. Standard errors are clustered by institution, and $* * *, * *$ and $*$ indicate significance at the $1 \%, 5 \%$ and $10 \%$ level, respectively 


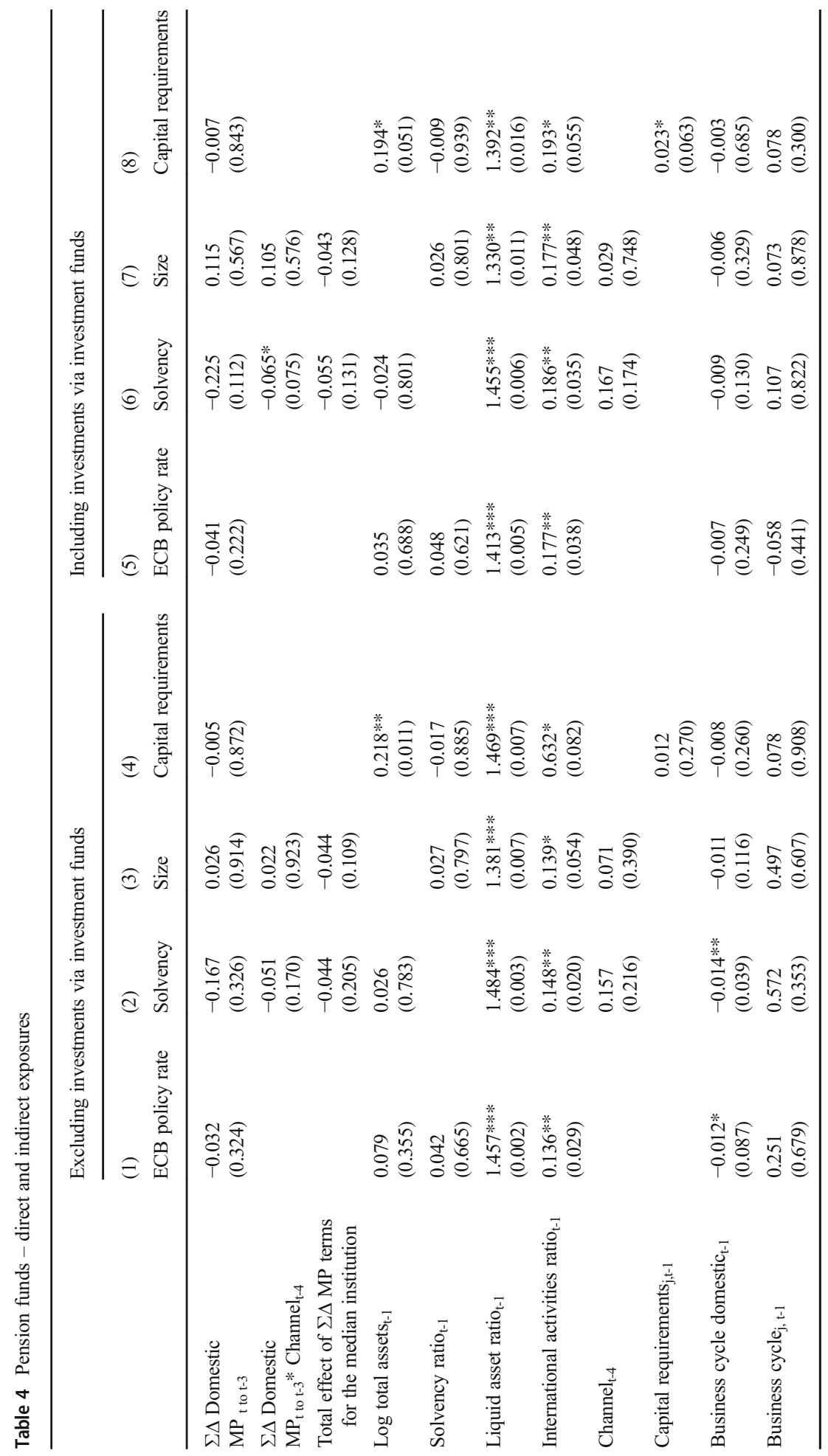




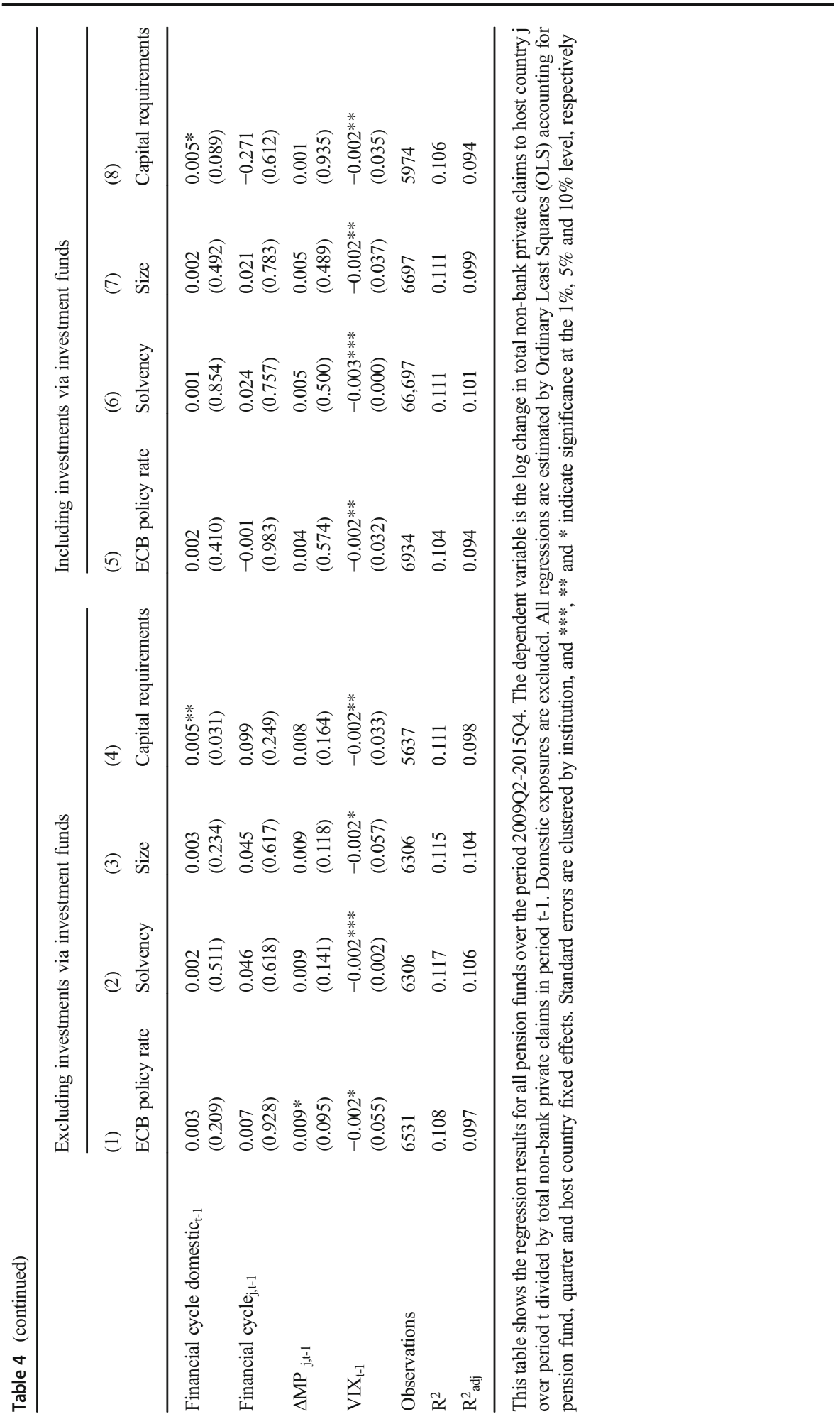


solvency and between monetary policy and pension funds' size. The overall impact, i.e. the cumulative effect of all coefficients, is similarly insignificant. The coefficient for host country capital requirements is positive, but not significant.

As mentioned previously, around 2009 pension funds started to invest more through investment funds. For the largest pension funds, we are able to "look through" the investments via investment funds. However, this is only possible from 2009Q2 onwards. For robustness, Table 4 therefore shows the regression results over the period 2009Q2-2015Q4, both including (columns 1-4) and excluding (columns 5-8) the investments via investment funds. The results are quite similar to the ones in Table 3. However, in the specification including investments via investment funds and in line with our findings for insurers we find some (weak) evidence that pension funds tend to increase their foreign lending to countries that increase their bank capital requirements. A further robustness check has considered the period before and after the ELB was reached, and again finds similar results.

\section{Conclusions}

Our results suggest that Dutch insurers and pension funds do not significantly change their foreign lending in response to ECB monetary policy changes. We do find evidence, however, that insurers and pension funds react to prudential policy changes. Both insurance companies and pension funds significantly increase their lending to countries where banks are getting more constrained by prudential regulation. This suggests cross-border substitution effects between banks and non-banks, which may attenuate the intended effects of prudential policies on lending markets and systemic stability. Further development of these insights is relevant for understanding how market structure influences international spillovers of monetary policy from different countries. More work could be done on cross-sector substitution. More work is notably needed to understand the impact of monetary and macroprudential policies on the international activities of shadow banks, including certain securitization vehicles and investment funds. A deeper understanding of the cross-border behavior of different institutions can help to inform monetary policy and macroprudential analysis. By helping to quantify spillovers, it can also inform the case for or against international monetary and regulatory coordination.

Acknowledgements The authors thank Jasper de Boer, Marjo de Jong, Jairo Rivera Rozo, Pieter Stam, Paul Witteman and Linda de Zeeuw for providing confidential insurer and pension fund data, and Henk van Kerkhoff for help with data compilation. We also like to thank two reviewers for their comments on a previous version of the paper. The views expressed here are those of the authors and do not necessarily reflect those of The Financial Stability Board and De Nederlandsche Bank.

Open Access This article is distributed under the terms of the Creative Commons Attribution 4.0 International License (http://creativecommons.org/licenses/by/4.0/), which permits unrestricted use, distribution, and reproduction in any medium, provided you give appropriate credit to the original author(s) and the source, provide a link to the Creative Commons license, and indicate if changes were made. 


\section{References}

Argimón I, Bonner C, Correa R, Duijm P, Frost J, de Haan J, de Haan L, Stebunovs V (2019) Financial institutions' business models and the global transmission of monetary policy. J Int Money Financ 90:99-117

Avdjiev S, Gambacorta L, Goldberg L, Schiaffi S (2016) The shifting drivers of global liquidity. Federal Reserve Bank of New York Staff Reports 819

Bank for International Settlements (2014) 84th annual report, debt and the financial cycle: domestic and global, Chapter IV, June

Bernanke B, Blinder A (1992) The Federal Funds Rate and the channels of monetary transmission. Am Econ Rev 82:901-921

Bruno V, Shin HS (2015) Capital flows and the risk-taking channel of monetary policy. J Monet Econ 71(C): 119-132

Buch C, Bussiere M, Goldberg L, Hills R (2019) The international transmission of monetary policy. J Int Money Financ 90:29-48

Cerutti E, Correa R, Fiorentino E, Segalla E (2017) Changes in prudential policy instruments - a new crosscountry database. Int J Cent Bank 13(S1):477-503

Cetorelli N, Goldberg L (2012) Banking globalization and monetary transmission. J Financ 67:1811-1843

Cizel J, Frost J, Houben A, Wierts P (2019) Effective macroprudential policy: cross-sector substitution from price and quantity measures. J Money Credit Bank forthcoming

Claus E, Claus I, Krippner L (2016) Asset markets and monetary policy shocks at the zero lower bound. Reserve Bank of New Zealand Working Paper DP2014/03a

Damar HE, Mordel A (2017) International banking and cross-border effects of regulation: lessons from Canada. Int J Cent Bank 13(S1):35-64

Drehmann M, Borio C, Tsatsaronis K (2011) Anchoring countercyclical capital buffers: the role of credit aggregates. BIS Working Papers, p 355

Frost J, van Horen N, de Haan J (2017) International banking and cross-border effects of regulation: lessons from the Netherlands. Int J Cent Bank 13(S1):293-313

Gagnon JE, Bayoumi T, Londono JM, Saborowski C, Sapriza H (2017) Direct and spillover effects of unconventional monetary and exchange rate policies. Open Econ Rev 28:191-232

International Monetary Fund (IMF) (2016) Monetary policy and the rise of nonbank finance. Global Financial Stability Report, October

Kashyap A, Stein J (2000) What do a million observations on banks say about the transmission of monetary policy? Am Econ Rev 90:407-428

Krippner L (2015) Zero lower bound term structure modeling: a practitioner's guide. Palgrave-Macmillan, London

Nsafoah D, Serletis A (2019) International monetary policy spillovers. Open Econ Rev 30(1):87-104

Ohls J, Pramor M, Tonzer L (2017) International banking and cross-border effects of regulation: lessons from Germany. Int J Cent Bank 13(S1):129-162

Pelizzon L, Sottocornola M (2016) The impact of the monetary policy interventions on the insurance industry. European Insurance and Occupational Pensions Authority (EIOPA) Financial Stability Report, December

van den Heuvel SJ (2002) Does bank capital matter for monetary transmission? Economic Policy Review Federal Reserve Bank of New York May, pp 259-265

Publisher's Note Springer Nature remains neutral with regard to jurisdictional claims in published maps and institutional affiliations. 